\title{
Bronchodilator responsiveness and atopy in 5-10-yr-old coughers
}

\author{
S.A. McKenzie, M. Mylonopoulou, P.D. Bridge
}

\begin{abstract}
Bronchodilator responsiveness and atopy in 5-10-yr-old coughers. S.A. McKenzie, M. Mylonopoulou, P.D. Bridge. (C)ERS Journals Ltd 2001.

ABSTRACT: Cough-variant asthma is considered by some to be an asthma phenotype. Bronchodilator responsiveness (BDR) is an undisputed feature of asthma. Of schoolaged wheezers, $90 \%$ are atopic. Are school-aged coughers who demonstrate BDR also atopic? If so, then it would be reasonable to reserve the diagnosis cough-variant asthma for this particular group.

Airway resistance was measured by the interrupter technique ( $R$ int) before and after salbutamol in controls $(n=73)$, coughers $(n=63)$ and previous wheezers $(n=63)$ aged 5-10 yrs. Immunoglobulin (Ig)-E was measured in coughers and wheezers. BDR was expressed as the ratio baseline:post-salbutamol $R$ int.

Groups were of similar age (mean 6.7, range 5-9.9 yrs). Geometric mean baseline $R$ int was similar in controls and coughers $\left(0.66\right.$ and $\left.0.68 \mathrm{kPa} \cdot \mathrm{L}^{-1} \cdot \mathrm{s}\right)$, but the baseline $R$ int for wheezers $\left(0.73 \mathrm{kPa} \cdot \mathrm{L}^{-1} \cdot \mathrm{s}\right)$ was greater than that for controls $(\mathrm{p}=0.05)$ but not significantly different from coughers $(p=0.17)$. Geometric mean BDR in coughers was 1.22, controls 1.13 and wheezers $1.30(p=0.01$ for coughers and controls; $p=0.08$ for coughers and wheezers; $p<0.001$ for controls and wheezers). IgE was lower in coughers than wheezers (geometric means 36 and 364 International Units (IU) $\cdot \mathbf{L}^{-1}, \mathbf{p}<0.001$ ) and was unrelated to BDR in both groups.

In summary, atopy, and not bronchodilator responsiveness, distinguishes groups of coughers from groups of wheezers. A diagnosis of cough-variant asthma cannot be reserved for even those school-aged coughers, who demonstrate bronchodilator responsiveness. Eur Respir J 2001; 18: 977-981.
\end{abstract}

Queen Elizabeth Children's Service Royal London Hospital

London

UK

Correspondence: S.A. McKenzie

Queen Elizabeth Children's Service

Royal London Hospital

Whitechapel

London

E1 1BB

UK

Fax: 442073777325

Keywords: Asthma

atopy

bronchodilating response

wheezing

Received: August 112000

Accepted after revision July 182001
One of the proposed asthma phenotypes is so-called cough-variant asthma and refers to persistent or recurrent cough without wheeze. However, schoolaged children with recurrent cough differ from children with wheeze in a number of clinical and epidemiological respects. In three studies, cough, unlike wheeze, was not related to bronchial hyperresponsiveness (BHR) or to atopy [1-3]. Two other studies have suggested that a family history of atopy and personal history of eczema and skin-prick sensitivity to house dust mite, are more common in children with cough than in controls but less than in wheezy children $[4,5]$. In preschool children, $\sim 50 \%$ of coughers demonstrate bronchodilator responsiveness (BDR) similar to wheezers of the same age. In neither coughers nor wheezers was this related to atopy [6] and the coughers resembled normals with respect to atopic status [7]. It is well recognized that persistent and late-onset wheezers are nearly all atopic [7]. Most nonatopic preschool wheezers, (transient wheezers), are no longer symptomatic after the age of $5 \mathrm{yrs}$. There are also fewer older children with recurrent cough $[8,9]$. If these school-aged coughers do not demonstrate BHR and are not atopic [1-3], do some demonstrate BDR like their preschool counterparts? Are those with BDR atopic like $90 \%$ of their wheezy peers? If so, then the term cough-variant asthma for children with recurrent or persistent cough, who demonstrate BDR, could be defended. Such a subgroup of coughers could represent those most likely to benefit from inhaled corticosteroids, a treatment known to be successful in atopic asthma.

The hypothesis was that schoolchildren with recurrent isolated cough demonstrate BDR and that this is related to serum total immunoglobulin (Ig)-E and allergen sensitization.

\section{Methods}

\section{Subjects}

This was a cross-sectional study. Children with recurrent or persistent cough (three episodes in the last 6 months or every day for three consecutive weeks, in the absence of fever, nasal discharge, snoring or other illness and on no treatment) were referred by family practitioners, who were asked by letter to refer such children to the local hospital children's chest clinic. Wheezers were consecutive referrals of children aged 5-10 yrs who, 4-6 weeks previously, were observed on examination by a doctor to have wheeze. These children had been seen in the ambulatory department of the hospital and were not 
wheezy at the time of testing. Controls with no history of cough, wheeze or difficulty in breathing were recruited by questionnaire from three local schools.

The study was approved by the local Ethics Committee.

Airway resistance, bronchodilator responsiveness testing, total serum immunoglobulin-E and skin-prick testing

Airway resistance was measured by the interrupter technique (Rint), as previously described [10], using two commercial devices (MicroRint and MicroLab 4000, Micromedical Ltd, Gillingham, UK). The difference in measurements made with these devices is no greater than the intrasubject repeatability with a single device $[10,11]$. Salbutamol $400 \mu \mathrm{g}$ was given using a spacer (Volumatic $\AA$, Allen and Hanbury's, Uxbridge, UK) and measurement of Rint was repeated 15 min later. In coughers and wheezers, IgE was measured by radioimmunoassay and skin-prick testing (SPT) to common aeroallergens (house dust mite, grass pollens, cat and dog danders and aspergillus) and to histamine and saline controls (ALK Abelló, Hørsholm, Denmark) was performed. A weal of $>3 \mathrm{~mm}$ to one prick classified a subject as SPT positive.

\section{Data analysis}

Data were analysed for normal distribution and transformed to $\log 10$ for analysis where appropriate. The transformed values were analysed by t-testing, simple and multiple regression. BDR was expressed as the ratio of baseline Rint to postsalbutamol Rint. Geometric means and their $95 \%$ confidence intervals (CI) were derived from the transformed values. SPT results in coughers and wheezers were compared by Chi-squared testing.

\section{Results}

\section{Subjects}

The characteristics in each group are presented in table 1.There were no significant differences in age or height between the groups, but there were fewer male coughers when compared to wheezers $(\mathrm{p}=0.02)$. Parents of coughers reported that children were troubled by coughing on the day of the test. All had previous episodes of cough and so were recurrent

Table 1. - Subject characteristics

\begin{tabular}{lccc}
\hline & Controls & Coughers & Wheezers \\
\hline Subjects n & 73 & 63 & 63 \\
M:F & $42: 31$ & $28: 35$ & $43: 20$ \\
age yrs & $6.8 \pm 1.34$ & $6.8 \pm 1.5$ & $6.5 \pm 1.3$ \\
height cm & $117.2 \pm 8.8$ & $120.8 \pm 12.8^{*}$ & $118.2 \pm 9.7$ \\
\hline
\end{tabular}

Data are presented as mean \pm SD. *: $\mathrm{n}=61$.
Table 2. - Baseline and postsalbutamol interruptor resistance, bronchodilator responsiveness (BDR) and immunoglobulin (Ig)-E measurements

\begin{tabular}{lcc}
\hline & Subjects n & Geometric mean 95\% CI \\
\hline $\begin{array}{l}\text { Baseline Rint } \\
\mathrm{kPa} \cdot \mathrm{L}^{-1} \cdot \mathrm{s}\end{array}$ & & \\
Controls & 73 & $0.66(0.62-0.70)$ \\
Coughers & 63 & $0.68(0.64-0.72)$ \\
Wheezers & 63 & $0.73(0.69-0.758)$ \\
Postsalbutamol Rint & & \\
$\mathrm{kPa} \cdot \mathrm{L}^{-1} \cdot \mathrm{s}$ & & \\
Controls & 73 & $0.58(0.55-0.62)$ \\
Coughers & 63 & $0.54(0.52-0.57)$ \\
Wheezers & 63 & $0.56(0.53-0.60)$ \\
BDR (baseline/ & & \\
postsalbutamol) & 73 & $1.13(1.10-1.17)$ \\
Controls & $61 *$ & $1.22(1.16-1.28)$ \\
Coughers & 63 & $1.30(1.24-1.36)$ \\
Wheezers & & $36(22-59)$ \\
IgE IU $\cdot \mathrm{mL} \mathrm{L}^{-1}$ & 43 & $364(234-537)$ \\
Coughers & 58 & \\
Wheezers & 58
\end{tabular}

Data are presented as mean $(95 \%$ confidence interval (CI)).

*: two outliers have been removed for analysis.

coughers, but in addition, fulfilled the definition of persistent coughers.

\section{Baseline measurements}

Measurements of baseline, postsalbutamol Rint, ratios of baseline:postsalbutamol $R$ int and $\operatorname{IgE}$ measurements are shown in table 2 and all baseline: postsalbutamol Rint measurements in figure 1. The two outliers in the coughing group (fig. 1) were excluded from analysis as their values exceeded 3 standard deviations of the mean. After their exclusion, transformed data were normally distributed.

There was no significant difference between baseline and postsalbutamol Rint in controls and coughers $(p=0.36$ and $p=0.17)$ or coughers and wheezers $(p=0.17$

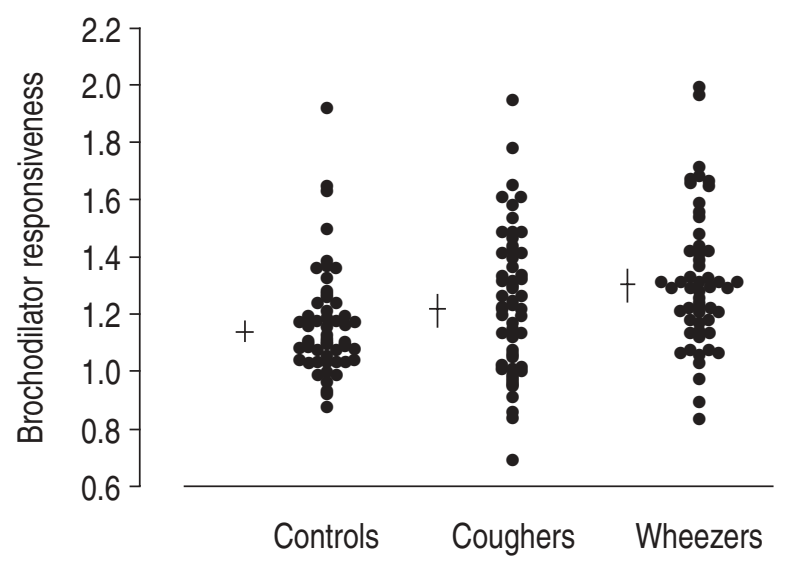

Fig. 1.-Bronchodilator responsiveness measurements in controls $(n=73)$, coughers $(n=63)$ and wheezers $(n=63)$. Lines shown are geometric means and $95 \%$ confidence intervals. Outliers for coughers: 2.9 and 2.4 . 
and $\mathrm{p}=0.47$ ). Although the wheezers' baseline for $R$ int was significantly higher than in the controls $(p=0.05)$, there was no difference in postsalbutamol Rint $(\mathrm{p}=0.33)$. BDR in both coughers and wheezers was significantly greater than in controls $(\mathrm{p}=0.01$ and $\mathrm{p}=<0.001)$. The BDR for coughers was intermediate between controls and wheezers, but did not differ significantly from wheezers $(\mathrm{p}=0.08)$.

IgE was significantly lower in coughers than in wheezers, and all but three of 43 measurements in coughers were within the normal range [7].

\section{Relationship of lung function with total serum immunoglobulin-E and skin-prick testing}

$\log \operatorname{IgE}$ was not related to age in this age range (regression coefficient was -0.0663 , SEM 0.0591, $\mathrm{p}=0.26$ ).

There was no relationship between logbaseline Rint or $\operatorname{logBDR}$ and sex in any of the three groups $(\mathrm{p}>0.10)$. logbaseline Rint, but not $\log \mathrm{BDR}$, was significantly related to age $(\mathrm{p}<0.001)$, but there was no significant difference between the regression coefficients for the three groups $\left(\mathrm{F}^{2} 193=1.30, \mathrm{p}=0.27\right)$. The common regression coefficient was -0.0333 (SEM 0.0053). Using this figure, baseline measurements were corrected for age (to age $5 \mathrm{yrs}$ ).

$$
\begin{aligned}
& \text { Age-corrected logbaseline } \\
& =\text { logbaseline }+(0.0333(\text { age- } 5))
\end{aligned}
$$

The relationships between age-corrected logbaseline, $\operatorname{logBDR}$ and $\log$ IgE are shown in table 3. This shows that neither baseline Rint measurements nor BDR are significantly related to IgE. The two coughers with very high $\mathrm{BDR}$ ratios had total serum $\mathrm{IgE}$ levels of 9 and $11 \mathrm{IU} \cdot \mathrm{L}^{-1}$, and the three coughers with very high IgE measurements had BDR measurements of 1.21 , 0.98 and 1.12 .

SPT was undertaken in 31 coughers and 58 wheezers. Three coughers $(10 \%)$ and $55(93 \%)$ wheezers were SPT positive $(\mathrm{p}<0.001)$.

\section{Discussion}

This study extends the previous work measuring $R$ int and BDR in children with respiratory symptoms. The interrupter method was chosen to measure airway

Table 3. - Relationship between baseline interruptor resistance and bronchodilator resistance and serum total immunoglobulin-E (IgE)

\begin{tabular}{lrllll}
\hline & $\begin{array}{c}\text { Age-corrected } \\
\text { logbaseline } \\
\text { versus logIgE }\end{array}$ & & \multicolumn{2}{c}{$\begin{array}{c}\text { Logratio versus } \\
\text { logIgE }\end{array}$} \\
\cline { 2 - 3 } \cline { 5 - 6 } & $\begin{array}{c}\text { Regression } \\
\text { coefficient }\end{array}$ & p-value & $\begin{array}{c}\text { Regression } \\
\text { coefficient }\end{array}$ & p-value \\
\hline Coughers & $-0.0263 \pm 0.0213$ & 0.22 & $-0.00716 \pm 0.0198$ & 0.36 \\
Wheezers & $0.0314 \pm 0.0212$ & 0.14 & & $0.0212 \pm 0.0150$ & 0.16 \\
\hline
\end{tabular}

Data are presented as mean \pm SEM. resistance in older children for two reasons. First, to compare measurements in school-age children with those made using Rint in preschool groups. Second, it has been shown that more children between 5-10 yrs are able to complete BDR testing with Rint than with forced expiratory manoeuvres [12].

This study has shown that, in children aged 5-10 yrs old, recurrent cough, the geometric mean baseline Rint, lay between and was not significantly different from that of controls and wheezers. This was also true in the preschool age group [6]. Although there were more males in the wheezer group, sex was unrelated to baseline Rint or BDR. The geometric mean BDR in coughers was intermediate between controls and wheezers, but the difference was not as high as that in the preschool groups [6]. However, although most of the wheezers were SPT positive and had abnormally high IgE levels, as in the preschool group [6], coughers had normal IgE measurements and $90 \%$ of those tested were SPT negative. The results for the coughers are very similar to those in preschool coughers [6]. It might have been expected that, since $\mathrm{BDR}$ is a feature of asthma, school-aged coughers who demonstrate BDR would be atopic as are most school-aged asthmatics, but this was not so. Recurrent coughers, then, irrespective of age, represent a group of children with respiratory symptoms and BDR, but without atopy. Although others have shown that coughers are no more atopic than controls [13], this is the first time the relationship between BDR and atopic status has been described. Thus, atopic status rather than BDR distinguishes school-age coughers from wheezers. The USA guidelines for the management of asthma recommend that the presence of BDR can be used for the diagnosis [14] but this will not help classify children with cough, when it is unclear from the history whether wheeze is present or not. However, the atopic status is helpful in classifying such children. This is important when a label of asthma is to be given and therapy is considered. Whilst the results here refer to a group of children, there will always be children who do not fit the model, i.e. coughers who do not perceive wheeze, who are atopic and who demonstrate BDR. Such children would resemble asthmatics. The present results suggest these are likely to be very few indeed.

If children with recurrent cough have few features of children with recurrent wheeze, then why should they demonstrate BDR? There is no evidence to suggest that older nonatopic coughers, such as those studied here, are or are not graduates of preschool nonatopic wheezers, a group who have been shown to demonstrate BDR [6]. What is known about the airway in adults with persistent cough suggests that airway inflammation, perhaps in response to infection and then only in sensitive individuals, is part of the pathophysiology of persistent cough [15]. Bronchial biopsies show increased epithelial desquamation and inflammatory cells, particularly mononuclear cells, suggesting airway inflammation. However, in children, differential cell counts in bronchoalveolar lavage are no different in those with cough compared to controls, unlike the inflammatory cells seen in wheezers [16]. It is difficult to compare cough studies 
in children because definitions differ. In population studies, it is unclear whether the coughers were coughing at the time of testing. One thing that appears to be in common is that cough is isolated. In population studies, coughers without reported wheeze are no more likely to demonstrate BHR than controls [1, 2]. However, coughers demonstrate BHR to hypertonic saline at the time of coughing [17], possibly reflecting epithelial damage and the priming of airway smooth muscle with inflammatory mediators, rendering them more sensitive to bronchoconstricting agents. There is little known about the relationship of the properties of airway smooth muscle, such as contractility and phenotype, to BHR, and nothing known about their relationship to BDR [18]. Surprisingly, it has been shown that BDR and BHR are only weakly related in asthmatic children [19]. Although an earlier study had shown that, in a group of selected asthmatic children, Rint was as sensitive as spirometry in demonstrating BDR [20], preliminary findings suggest that Rint is more sensitive than spirometry in identifying BDR in a group of unselected children with respiratory symptoms [21]. It would be interesting to compare BDR and BHR in children with persistent cough using Rint. Epithelial damage, mediator release and increased sensitivity of parasympathetic receptor reflexes, which include the cough reflex, are known to occur in rhinoviral infection [22]. Rhinovirus replication persists for up to 3 weeks, long enough to cause persistent symptoms, at least in some subjects. It has been shown that children with persistent cough have increased cough receptor sensitivity (CRS) at the time of the cough, which could be related to increased sensitivity of parasympathetic reflexes [17]. It is possible that rhinovirus infection could be responsible for persistent cough and BDR in susceptible subjects. This study has shown that, in addition to the observations of others of increased BHR and CRS at the time of coughing [17, 23], there is also increased BDR. If BDR returns to normal when cough resolves, then a common reason for both BDR and cough would be suggested. It will be important to follow these children with repeat studies at a time when they have been free of cough for some weeks.

If bronchodilator responsiveness is demonstrated during cough, then will bronchodilators relieve the symptom of cough? It has been shown that nocturnal cough does not improve in asthmatic children treated with a bronchodilator [24]. Only one study has investigated the effect of continuous bronchodilator treatment in children with isolated cough [13], with no effect demonstrated. If inflammation underpins persistent cough, then corticosteroid treatment might be expected to help. A modest benefit has been demonstrated after 2 weeks of high-dose corticosteroids [25]. Therefore, the term "cough-variant" asthma should be dropped as it can encourage misclassification of coughers as asthmatics and inappropriate prescribing of asthma treatment [26]. There is enough known about children with isolated cough to distinguish them from those with wheeze and asthma and to support the term "recurrent or persistent isolated cough" as a diagnostic category.

\section{References}

1. Clifford RD, Howell JB, Radford M, Holgate ST. Associations between respiratory symptoms, bronchial response to methacholine, and atopy in two age groups of schoolchildren. Arch Dis Child 1989; 64: $1133-1139$.

2. Clough JB, Williams JD, Holgate ST. Profile of bronchial responsiveness in children with respiratory symptoms. Arch Dis Child 1992; 67: 574-579.

3. Wright AL, Holberg CJ, Morgan WJ, Taussig LM, Halonen M, Martinez FD. Recurrent cough in childhood and its relation to asthma. Am J Respir Crit Care Med 1996; 153: 1259-1265.

4. Ninan TK, Macdonald L, Russell G. Persistent nocturnal cough in childhood: a population based study. Arch Dis Child 1995; 73: 403-407.

5. Lewis HM, Haeney M, Jeacock J, Thomas H. Chronic cough in a hospital population; its relationship to atopy and defects in host defence. Arch Dis Child 1989; 64: 1593-1598.

6. McKenzie SA, Bridge PD, Healy MJR. Airways resistance in pre-school children with wheeze and cough. Eur Respir J 1999; 15: 833-838.

7. Wittig HJ, Belloit J, De FI, Royal G. Age-related serum immunoglobulin $E$ levels in healthy subjects and in patients with allergic disease. J Allergy Clin Immunol 1980; 66: 305-313.

8. Clifford RD, Radford M, Howell JB, Holgate ST. Prevalence of respiratory symptoms among 7 and 11 year old schoolchildren and association with asthma. Arch Dis Child 1989; 64: 1118-1125.

9. Fuller P, Picciotto A, Davies M, McKenzie SA. Cough and sleep in inner-city children. Eur Respir $J$ 1998; 12: 426-431.

10. Bridge PD, Ranganathan S, McKenzie SA. The measurement of airway resistance using the interrupter technique (Rint) in pre-school children in the ambulatory setting. Eur Respir J 1999; 13: 792-796.

11. Lombardi E, Novembre E, Bridge PD, Bernardini R, Sgarra L, Vierrucci A. Comparison of two devices for assessment of interrupter resistance in children. Eur Respir J 1999; 14: Suppl. 30, 375.

12. Bridge PD, McKenzie SA. Bronchodilator responsiveness testing in young children. Arch Dis Child 2001; 84: 525.

13. Chang AB, Phelan PD, Carlin JB, Sawyer SM, Robertson CF. A randomised, placebo controlled trial of inhaled salbutamol and beclomethasone for recurrent cough. Arch Dis Child 1998; 79: 6-11.

14. National Asthma Education and Prevention Programme. Guidelines for the Diagnosis and Management of Asthma. National Institutes of Health. Clinical Practice Guidelines. Bethesda, USA, 1997; 2: 15-17.

15. Boulet LP, Milot J, Boutet M, St Georges F, Laviolette M. Airway inflammation in nonasthmatic subjects with chronic cough. Am J Respir Crit Care Med 1994; 149: 482-489.

16. Marguet C, Jouen-Boedes F, Dean TP, Warner JO. Bronchoalveolar cell profiles in children with asthma, infantile wheeze, chronic cough, or cystic fibrosis. $\mathrm{Am}$ J Respir Crit Care Med 1999; 159: 1533-1540.

17. Chang AB, Phelan PD, Sawyer SM, Robertson CF. Airway hyperresponsiveness and cough-receptor sensitivity in children with recurrent cough. Am J Respir Crit Care Med 1997; 155: 1935-1939. 
18. Gunst SJ, Tang DD. The contractile apparatus and mechanical properties of airway smooth muscle. Eur Respir J 2000; 15: 600-616.

19. Waalkens HJ, Merkus PJ, Van Essen-Zandvliet EE, et al. Assessment of bronchodilator response in children with asthma. Dutch CNSLD Study Group. Eur Respir J 1993; 6: 645-651.

20. Bridge PD, Lee H, Silverman M. A portable device based on the interrupter technique to measure bronchodilator response in schoolchildren. Eur Respir $J$ 1996; 9: 1368-1373.

21. Bridge PD, Mylonopoulou M, McKenzie SA. Comparison of bronchodilator responsiveness measured by the interrupter technique and spirometry in $5<10$ year olds in an ambulatory environment. Eur Respir $J$ 2000; 16: Suppl. 31, 385S.

22. Gwaltney JMJ. Rhinovirus infection of the normal human airway. Am J Respir Crit Care Med 1995; 152: S36-S39.

23. Chang AB, Phelan PD, Sawyer SM, Del Brocco S, Robertson CF. Cough sensitivity in children with asthma, recurrent cough, and cystic fibrosis. Arch Dis Child 1997; 77: 331-334.

24. Hoskyns EW, Thomson A, Decker E, Hutchins A, Simpson H. Effect of controlled release salbutamol on nocturnal cough in asthma. Arch Dis Child 1991; 66: 1209-1212.

25. Davies MJ, Fuller P, Picciotto A, McKenzie SA. Persistent nocturnal cough: randomised controlled trial of high dose inhaled corticosteroid. Arch Dis Child 1999; 81: 38-44.

26. Picciotto A, Hubbard M, Sturdy P, Naish J, McKenzie SA. Prescribing for persistent cough in children. Respir Med 1998; 92: 638-641. 